\title{
Utilization of anti-peptic ulcer drugs in outpatient clinics of Paonta Sahib, Himachal Pradesh, India
}

\author{
Bhumika Mangla, Naina Bhardwaj, Satinder Kakar* \\ Department of Pharmacy, Himachal Institute of Pharmacy, Paonta Sahib, Himachal Pradesh, India
}

ABSTRACT
Objective: The aim is to know the utilization of anti-peptic ulcer drugs in outpatient clinics of Paonta Sahib, Himachal Pradesh,
India.
Materials and Methods: Data were collected from October 2017 to Feburary 2018 by visiting outpatient departments of the
hospital for 2 weeks each and reviewing the prescriptions during the study period.
Results: The most common form was tablets ( $36 \%)$, followed by capsules (11\%) and liquid formulations (8\%). The use of injectable
preparations of anti-peptic ulcer drugs was in the current study which was similar with the average results (40\%) of drug utilizations
studies on different classes of drugs in Poanta Sahib.
Conclusion: Lasix injection is the most common antiseptic ulcer drugs prescribed.
Key words: Anti-ulcer, clinic, drugs, Himachal Pradesh, outpatient

\section{INTRODUCTION}

Ulcer is a sore on the surface of the body, caused by a break in the skin which fails to heal. Various ulcers range from small, painful sores in the mouth and serious lesions of the stomach. ${ }^{[1]}$

Synonyms for ulcer include sore, ulceration, open sore, abscess, boil, carbuncle, pustule, blister, and cyst.

\section{Causes of Ulcer}

Stress, avoid water, fasting condition, increase intake of nonsteroidal anti-inflammatory drugs (NSAID'S), and overdose of aspirin are causes of ulcer. ${ }^{[2]}$

Peptic ulcer is a serious medical problem. Each year, 500,000 new cases are reported, and 5 million people affected in the United States alone. Generations born around the middle of the $20^{\text {th }}$ century are at highest risk. Ulcer disease affects the older population, with the peak incidence occurring between 55 and 65 years of age. In men, duodenal ulcers were more common than gastric ulcers; in women, the reverse was found to be true. Mortality rates from peptic ulcer are low.

Ulcers can develop in the esophagus, stomach, at the margin of a gastroenterostomy, and jejunum. Peptic ulcer disease is the disorder of the upper gastrointestinal tract that is caused by gastric acid partially. Patients with peptic ulcer present a range of symptoms, from mild abdominal discomfort to catastrophic perforation and bleeding. ${ }^{[3]}$

\section{What is Peptic Ulcer Disease?}

Gastric and duodenal ulcers are breaks in the gastric and duodenal mucosa. Both ulcers relate to the corrosive action of pepsin and hydrochloric acid on the mucosa of the upper gastrointestinal tract. Ulcers generally range between $3 \mathrm{~mm}$ and several centimeters in diameter.

\section{Symptoms}

Symptoms include abdominal discomfort, pain, or nausea. The pain is located in the epigastrium. Symptoms are neither sensitive nor specific. Pain radiating to the back may suggest that an ulcer may be pancreatic in origin. Pain radiating to the right upper quadrant may suggest disease of the gallbladder. Pain of peptic ulcer is burning or as hunger pains slowly building up for 1-2 h. The use of antacids may provide temporary relief. Classically, gastric ulcer pain is aggravated by meals, whereas the pain of duodenal ulcers is relieved by meals. ${ }^{[4,5]}$

\section{Complications of Peptic Ulcers}

- Hemorrhage

- Perforation

- Narrowing and obstruction (pyloric). ${ }^{[2]}$

\section{There are Three Types of Peptic Ulcers} Types of ulcers

Some of the most common types of ulcers are as follows:

i. Gastric ulcers,

ii. Duodenal ulcers, and

iii. Peptic ulcer.

Address for correspondence:

Bhumika Mangla, Department of Pharmacy, Himachal Institute of Pharmacy, Paonta Sahib, Himachal Pradesh, India.

E-mail: satinder.kakkar5@gmail.com

Received: 07-04-2018, Revised: 18-05-2018, Accepted: 20-06-2018 
Ulcers are named for their location within the body. Pepsin exposed ulcers are called peptic ulcers. Pepsin in human beings is normally there in the stomach lining with hydrochloric acid. Some patients will also have to take antibiotics as a treatment for peptic ulcer.

\section{Gastric Ulcer}

When a peptic ulcer occurs in the stomach, it is called a gastric ulcer. The bacterium called Helicobacter pylori causes this type of ulcer. Antacids are used as a treatment option of gastric ulcer. Furthermore, the ulcer patients are advised not to use too much oily and greasy food [Figure 1].

\section{Duodenal Ulcer}

Duodenal ulcers are kind of peptic ulcers but located in the duodenum. Usually, patients feel a burning sensation and heartburn feelings. Duodenum ulcers will usually begin in the starting point of the small intestine.

Four less common types are as follows:

i. Esophageal ulcer: Esophageal ulcer usually occurs in the lower end of a patient esophagus. Antibiotics are recommended for this. Esophageal ulcer patients may also feel a lot of pain sometimes and this pain will increase as the ulcer will come in contact with the acid present in the stomach. ${ }^{[6,7]}$

ii. Bleeding ulcer: Sometimes, internal bleeding is caused by a peptic ulcer if that ulcer has been left untreated for a long time. When this occurs, it is now referred to as a bleeding ulcer. It requires an immediate treatment.

iii. Refractory ulcer: Simple peptic ulcers that have not healed after at least 3 months of treatment are called refractory ulcers.

iv. Stress ulcer: Stress ulcers consist of a group of lesions and usually found in the esophagus, stomach, or duodenum. Stress ulcer is normally present in the people who have other illness or are critically ill. Stress ulcer will usually go automatically once the stress level goes down. ${ }^{[6]}$

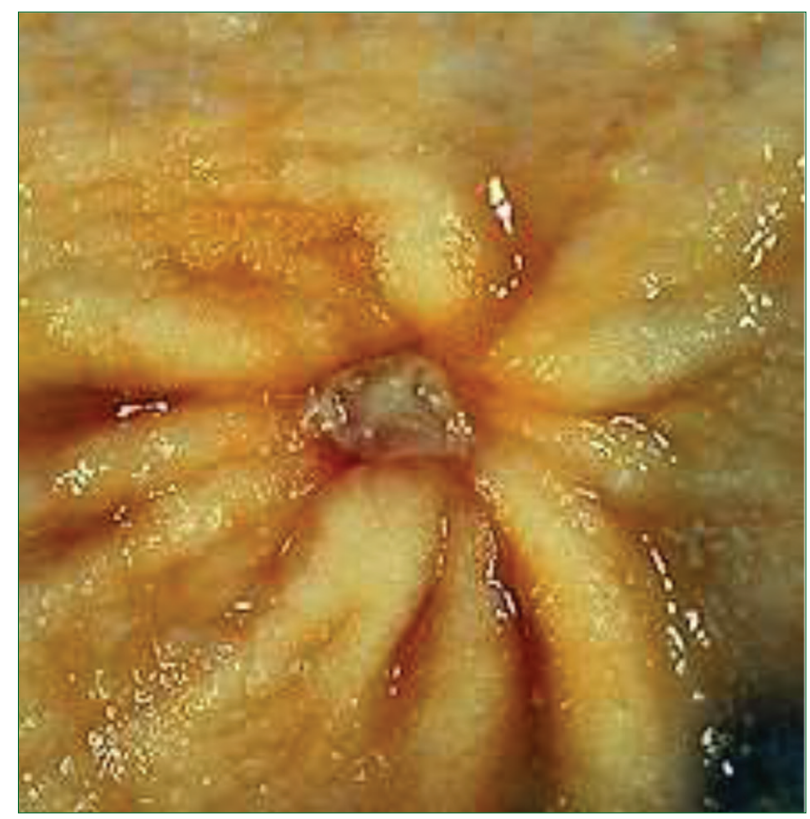

Figure 1: Gastric ulcer

\section{Anti-ulcer Drugs}

Antiulcer is defined as those agents which are used to treat ulcers in the stomach and the upper part of the small intestine. ${ }^{[7]}$

\section{Classification of Anti-ulcer Drugs}

1. Reduction of gastric acid:

a. $\mathrm{H}_{2}$ antihistamines: Cimetidine, ranitidine

b. Proton pump inhibitors: Omeprazole, lansoprazole

c. Anticholinergics: Porenzapine, propantheline

d. Prostaglandin analogues: Misoprost0l, enprostil.

2. Neutralization of gastric acid:

a. Systemic: Sodium bicarbonate $\left(\mathrm{NaHCO}_{3}\right)$

b. Non-systemic: Magnesium hydroxides, magnesium trisilicate, aluminum hydroxide gel, magaldrate calcium.

3. Ulcer protective agents: Sucralfate, colloidal bismuth subcitrate.

4. Ulcer healing agents: Carbenoxolone sodium.

5. Anti-H. pylori drugs: Amoxicillin, clarithromycin, metronidazole, tinidazole, tetracycline.

Anti-ulcer drugs: These are discussed in Table 1.

Purpose: Recurrent gastric and duodenal ulcers are caused by $H$. pylori infections and are treated with combination treatments that incorporate antibiotic therapy with gastric acid suppression. In addition, bismuth compounds have been used. The primary class of drugs used for gastric acid suppression are the proton-pump inhibitors, omeprazole, lansoprazole, pantoprazole, and rabeprazole. ${ }^{[8-12]}$ The $\mathrm{H}-2$ receptor blocking agents, cimetidine, famotidine, nizatidine, and ranitidine have been used for this purpose. Sucralfate, which acts by forming a protective coating over the ulcerate lesion, is also used in ulcer treatment and may be appropriate for patients in whom other classes of drugs are not indicated or those whose gastric ulcers are caused by NSAIDs rather than $H$. pylori infections. ${ }^{[13-15]}$

\section{MATERIALS AND METHODS}

\section{Objective}

\section{The objectives are to study}

1. Number of patient coming for treatment regarding peptic ulcer.

\begin{tabular}{ll}
\hline $\begin{array}{l}\text { Table 1: Anti-ulcer drugs along with their side } \\
\text { effects }\end{array}$ \\
\hline Anti-ulcer drugs & $\begin{array}{l}\text { Possible common side effects include } \\
\text { Diarrhea, headache, sore throat } \\
\text { Constipation, insomnia, hives, upset } \\
\text { stomach, vomiting }\end{array}$ \\
\hline $\begin{array}{l}\text { Brand name (generic name) } \\
\text { Carafate (sucralfate) }\end{array}$ & $\begin{array}{l}\text { Constipation or diarrhea, dizziness, } \\
\text { fever }\end{array}$ \\
$\begin{array}{l}\text { Cytotec (misoprostol) } \\
\text { Pepcid (famotidine) }\end{array}$ & $\begin{array}{l}\text { Nausea and vomiting, headache, } \\
\text { diarrhea, abdominal pain }\end{array}$ \\
Prilosec (omeprazole) & $\begin{array}{l}\text { Headache, breast development in } \\
\text { men, depression } \\
\text { Headache, constipation or diarrhea, } \\
\text { joint pain }\end{array}$ \\
\hline
\end{tabular}


2. Number of drug sold.

3. Most recommended brands of drug for peptic ulcer.

4. Maximum selling price of peptic ulcer drug.

\section{Methodology}

This was a cross-sectional observational study approved by the Institutional Ethics Committee. Data were collected from October 2017 to February 2018 by visiting outpatient departments of the tertiary care hospital for 2 weeks each and reviewing the prescriptions during study period. Written informed consent was obtained from the prescribing doctors and patients for viewing their prescriptions. Approximately 300 prescriptions were studied, and 50 prescriptions containing anti-peptic ulcer agents found were analyzed in the study. Prescribed drugs were classified according to their pharmacological class. For information on cost, formulation of the prescribed drugs CIMS and drug today were referred. Prescribed drugs were categorized as single drugs or fixeddose combinations (FDCs) and whether they were prescribed by generic or brand name. In this study, the percentage of the cost difference in the maximum and minimum price of the same drug manufactured by different pharmaceutical companies has been calculated.

\section{RESULTS}

Table 2 shows the number of patients coming for treatment regarding peptic ulcer. Table 3 shows a number of drugs sold.

\author{
Maximum selling price of peptic ulcer drug \\ a. Ondansetron \\ b. Pantoprazole \\ c. Derylli \\ d. Lasix Table 4
}

Table 5 shows maximum selling price of peptic ulcer drugs.

\section{DISCUSSION}

This study is the first one of its kind in which all the groups of anti-peptic ulcer drugs have been reviewed in multiple specialties of a hospital. Literature search has shown that studies have

Table 2: Number of patients coming for treatment regarding peptic ulcer

\begin{tabular}{lc}
\hline Characteristics & Patients $\boldsymbol{n = 5 0}$ \\
\hline Age group (years) & 6 \\
$0-15$ & 7 \\
$16-30$ & 11 \\
$31-45$ & 10 \\
$46-60$ & 16 \\
$61-75$ & \\
Gender & 24 \\
Male & 26 \\
Female & \\
Occupation & 27 \\
Physical work & 12 \\
Non-working/household & 11 \\
Student & \\
\hline
\end{tabular}

either concentrated on one particular acid suppressant group like PPI or authors have done such studies in specialty clinics such as gastroenterology, intensive care units, hospitalized patients, orthopedic clinics, or discharge letters to study their utilization. The results of this study show that three of four anti-peptic ulcer drugs (APUDs) prescribed were either from orthopedic or medicine OPDs. Doctors from the department of psychiatry were seen quite cautious about using APUDs, and only one prescription of APUD was found in 2 weeks' duration. This observation was justified, as the psychiatrists routinely prescribed drugs which were least gastroirritant and they only

\begin{tabular}{lccc}
\hline Table 3: Number of drug sold & & \\
\hline Drugs & $\begin{array}{c}\text { Maximum } \\
\text { price (Rs) }\end{array}$ & $\begin{array}{c}\text { Minimum } \\
\text { price (Rs) }\end{array}$ & $\begin{array}{c}\text { Average } \\
\text { price (Rs) }\end{array}$ \\
\hline Ondansetron max & 45 & 40 & 435 \\
Pantoprazole max & 110 & 95 & 1025 \\
Drotervin & 40 & 35 & 375 \\
Diclofenac & 18 & 16 & 17 \\
Hydrocortisone max & 38 & 33 & 355 \\
Lasix max & 385 & 3.40 & 36 \\
Piperacillin & 200 & 175 & 1875 \\
Rabeprazole & 70 & 60 & 65 \\
Telmisartan & 60 & 50 & 55 \\
Derylline max & 4 & 370 & 385 \\
Doxi & 11 & 10 & 10.5 \\
Roko (capsule) & 15 & 13 & 14 \\
Movicol & 40 & 35 & 37.5 \\
Azithromycin & 55 & 48 & 525 \\
\hline
\end{tabular}

Table 4: Most recommended brands of drug for peptic ulcer

\begin{tabular}{lccc}
\hline Drugs & $\begin{array}{c}\text { Maximum } \\
\text { price (Rs) }\end{array}$ & $\begin{array}{c}\text { Minimum } \\
\text { price (Rs) }\end{array}$ & $\begin{array}{c}\text { Average } \\
\text { price (Rs) }\end{array}$ \\
\hline Ondansetron & 45 & 40 & 43.5 \\
Pantoprazole & 110 & 70 & 43.5 \\
Drotervin & 40 & 35 & $37 \cdot 5$ \\
Diclofenac & 18 & 16 & 17 \\
Hydrocortisone & 38 & 33 & 35.5 \\
Lasix max & 385 & 3.40 & 36 \\
Piperacillin & 200 & 175 & 1875 \\
Rabeprazole & 70 & 60 & 65 \\
Telmisartan & 60 & 50 & 55 \\
Derylline & 4 & 3.70 & 385 \\
Doxi & 11 & 10 & 10.5 \\
Roko (capsule) & 15 & 13 & 14 \\
Movicol & 40 & 35 & 375 \\
Azithromycin & 55 & 48 & 525 \\
\hline
\end{tabular}

Table 5: Maximum selling price of peptic ulcer drug

\begin{tabular}{lccc}
\hline Drugs & $\begin{array}{c}\text { Maximum } \\
\text { price (Rs) }\end{array}$ & $\begin{array}{c}\text { Minimum } \\
\text { price (Rs) }\end{array}$ & $\begin{array}{c}\text { Average } \\
\text { price (Rs) }\end{array}$ \\
\hline Ondansetron & 45 & 40 & 43.5 \\
Pantoprazole & 110 & 95 & 102.5 \\
Lasix max & 3.85 & 3.40 & 3.6 \\
Derylline max & 4 & 3.70 & 3.85 \\
\hline
\end{tabular}




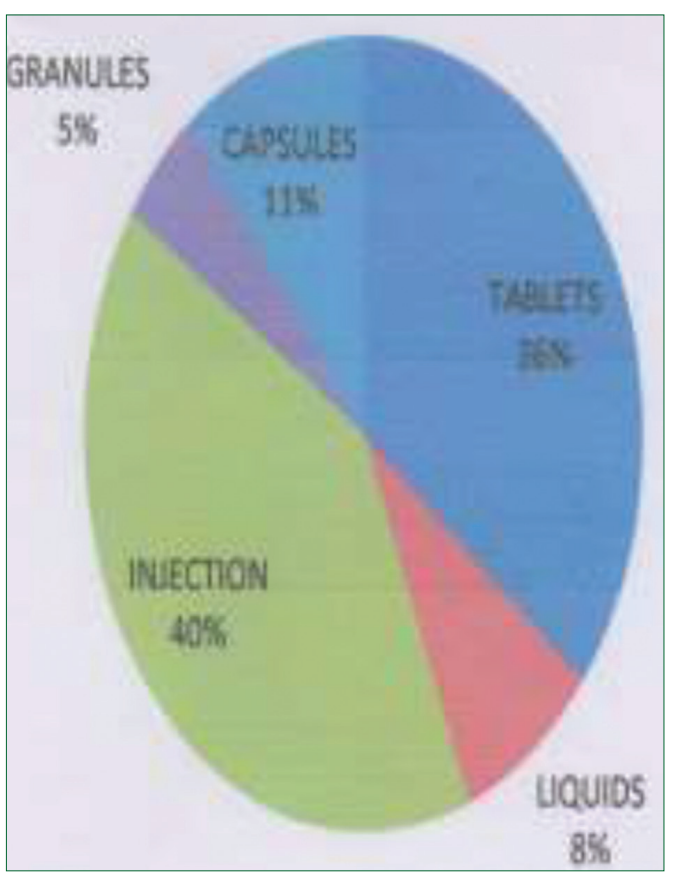

Figure 2: Anti-peptic ulcer drugs different formulations

preferred to prescribe APUDs in patients VI significant history of acid peptic symptoms. Similarly, less utilization of these APUD drugs was also seen in ophthalmology and pediatric department which is rationally justified. Different formulations of APUDs prescribed on OPD basis were also studied. In the present study, 95\% APUDs were prescribed by oral route and the most common form was tablets (36\%), followed by capsules (11\%) and liquid formulations (8\%). Use of injectable preparations of APUDs in the current study which was similar with the average results (40\%) of drug utilization studies on different classes of drugs in Paonta Sahib [Figure 2].

\section{CONCLUSION}

Lasix injection is the most common antiseptic ulcer drugs prescribed. FDC and recently introduced drugs in this class of acid suppressants were very common in outpatient of the civil hospital, Paonta Sahib.

\section{REFERENCES}

1. Yang $Y X$, Lewis JD, Epstein S, Metz DC. Long-term proton pump inhibitor therapy and risk of hip fracture. JAMA 2006;296:2947-53.

2. Aviello G, Romano B, Borrelli F, Capasso R, Gallo L, Piscitelli $F$, et al. Chemopreventive effect of the nonpsychotropic phytocannabinoid cannabidiol on experimental colon cancer. J Mol Med 2002;35:523-34.

3. Scanlon VC. Tina Ssnders. Essential of Anatomy and Physiology. $5^{\text {th }}$ ed. Philadelphia, PA: N K H AT U Y O Antiulcer Drugs Classification; 2011.

4. Lau WY, Leow CK. History of perforated duodenal and gastric ulcers. World J Surg 1997;21:890-6.

5. Bertleff MJ, Lange JF. Perforated peptic ulcer disease: A review of history and treatment. Dig Surg 2010;27:161-9.

6. Slade $\mathrm{H}$, Howell HS. When repair is enough for perforated duodenal ulcer. Contemp Surg 2008;64:523.

7. Lagoo S, McMahon RL, Kakihara M, Pappas TN, Eubanks S. The sixth decision regarding perforated duodenal ulcer. JSLS 2002;6:359-68.

8. Ahmed N. 23 years of the discovery of Helicobacter pylori: Is the debate over? Ann Clin Microbiol Antimicrob 2005;4:17.

9. Malfertheiner P, Megraud F, O'Morain CA, Atherton J, Axon AT, Bazzoli $\mathrm{F}$, et al. Management of Helicobacter pylori infection-the Maastricht IV/Florence consensus report. Gut 2012;61:646-64.

10. van Doorn LJ. Detection of Helicobacter pylori virulenceassociated genes. Expert Rev Mol Diagn 2001;1:290-8.

11. Zittel TT, Jehle EC, Becker HD. Surgical management of peptic ulcer disease today-Indication, technique and outcome. Langenbecks Arch Surg 2000;385:84-96.

12. Bhogal RH, Athwal R, Durkin D, Deakin M, Cheruvu CN. Comparison between open and laparoscopic repair of perforated peptic ulcer disease. World J Surg 2008;32:2371-4.

13. Lee FY, Leung KL, Lai BS, Ng SS, Dexter S, Lau WY. Predicting mortality and morbidity of patients operated on for perforated peptic ulcers. Arch Surg 2001;136:90-4.

14. Ballinger A, Smith G. COX-2 inhibitors vs. NSAIDs in gastrointestinal damage and prevention. Expert Opin Pharmacother 2001;2:31-40.

15. Huang JQ, Sridhar S, Hunt RH. Role of Helicobacter pylori infection and non-steroidal anti-inflammatory drugs in pepticulcer disease: A meta-analysis. Lancet 2002;359:14-22.

How to cite this Article: Mangla S, Naina, Kakar S. Utilization of anti-peptic ulcer drugs in outpatient clinics of Paonta Sahib, Himachal Pradesh, India. Int. Res. Med. Health Sci., 2018; 1(1):21-24.

Source of Support: Nil, Conflict of Interest: None declared. 